\section{Ecotoxicity of a potential drug nano-formulation: PAMAM-dendrimer and minocycline}

\section{Blaise, ${ }^{1}$ F. Gagné, ${ }^{1}$ J. Auclair, ${ }^{1}$ D. Maysinger, ${ }^{2}$ P. Sutthivaiyakit ${ }^{3}$}

${ }^{1}$ Aquatic Contaminants Research Division, Environment Canada, Montréal, QUE, Canada; 'Department of Pharmacology and Therapeutics, McGill University, QUE, Canada; ${ }^{3}$ Department of Chemistry and Center of Excellence for Innovation in Chemistry, Kasetsart University, Bangkok, Thailand

\section{Introduction}

The varied composition, size, and shape of nanomaterials (1-100 $\mathrm{nm}$ size range) offer numerous exciting possibilities for the development of new industrial, biomedical, electronic products and have the potential to stimulate the global economy. ${ }^{1}$ On the darker side, the marked research efforts presently deployed to develop novel applications with nanomaterials will eventually lead to some releases in the aquatic environment likely via urban industrial/municipal point sources of pollution. This is clearly cause for concern as recent studies suggest that adverse health ${ }^{2,3}$ and environmental ${ }^{4,5}$ effects are linked to nanoproduct pollutants.

In the biomedical field, drug delivery systems combining nano-dendrimers (as a platform for delivery) and specific guest molecules (e.g. pharmaceuticals) are being investigated for efficient treatment of diseases (e.g., cancer, inflammation, cardiac and microbial problems). ${ }^{6}$ While characteristics (molecular size, shape, dimension, density, polarity, flexibility, solubility, drug carrying capacity, etc.) of dendrimers will vary based on their construction, ${ }^{7}$ cationic dendrimers are among the most common candidates in terms of pharmaceutical development and they are being considered for the drug delivery of anti-microbials such as minocycline. ${ }^{8}$ In this study, we investigated the ecotoxicity of three PAMAM dendrimers (artificial macromolecules with tree-like structures, described in the methods section, and of minocycline, individually and in combination by conducting toxicity tests with microorganisms representing different levels of biological organization. Our objectives are to obtain preliminary information on the potential hazard of PAMAM dendrimers and minocycline.

\section{Materials and Methods}

Three PAMAM (poly-amidoamine) dendrimers, made up of a 1,4-diaminobutane core, were purchased from Sigma Chemical Co., USA. We specifically studied PAMAM Generation 2, 4 and 5 dendrimers, characterized by 16 (G2), 64 (G4) and 128 (G5) $\mathrm{NH}_{2}$ surface groups, respectively. ${ }^{6}$ The antibiotic minocycline (MC) was purchased from Sigma Chemical Co., USA. Characteristics of bioassays conducted to assess dendrimers and MC toxicity are highlighted in Table $1 .^{9-12}$ References listed in this table can be consulted for more ample details on testing procedures. Measurement endpoints generated with the bioassays for individual substances tested were determined with statistical methods and software recommended for each procedure. For interactive toxicity testing (e.g., dendrimer G4 and MC), the experimental approach employed is described in the following section.

\section{Results and Discussion}

Classifying bioassay data as a result of toxicity tests conducted in Table 1 , according to EU-Directive 93/67/EEC, ${ }^{13}$ offers some estimate of hazard potential for the PAMAM dendrimers and MC studied (Table 2). These comparative bioassay responses indicate that the spectrum of toxicity encompasses all cut-off classes (i.e., from harmful to extremely toxic) for dendrimers G2, G4 and/or G5 and from not toxic to extremely toxic for MC. Clearly, this wide range of sensitivity justifies the continued use of representative species within test batteries to properly appraise the toxic potential of PAMAM dendrimers, since responses can be biological level-, test procedure- and endpoint specific (Table 2). Phototrophic test systems (i.e., algal and LuminoTox assays) and the Hydra assay appear particularly sensitive to the toxic effects of dendrimers G2, G4 and G5, as all of their responses, barring one (LuminoTox response for G2), fall into the very toxic to extremely toxic category. Expectedly, the antibiotic MC showed greater toxicity in bioassays with microorganisms (algal and bacterial tests) and subcellular photosynthetic enzyme complexes (PECs of the LuminoTox test) as their responses were all generated in the toxic and extremely toxic classes compared to not toxic and harmful classes in the fish, hydra and micro-invertebrate (T. platyurus) bioassays. In light of this initial toxicity data, bioassay batteries comprised of the LuminoTox, algal and hydra tests should be used for future determination of the toxic potential of PAMAM dendrimeric nanomaterials due to their high sensitivity.
Correspondence: Christian Blaise and François Gagné, Aquatic Contaminants Research Division, Environment Canada, 105 McGill, 7th floor, Montréal, QUE, Canada, H2Y 2E7.

E-mails: christian.blaise@ec.gc.ca;

francois.gagne@ec.gc.ca

Key words: nanomaterials, environment, nanoproduct pollutants.

Conference presentation: ECOBIM meeting, 2014 May, Brest, France.

Acknowledgments: this work was jointly funded by the Nano-CEPA (Nanomaterials - Canadian Environmental Protection Act) program of Environment Canada and by the CMP (Chemicals Management Plan) program of Health Canada.

This work is licensed under a Creative Commons Attribution NonCommercial 3.0 License (CC BYNC 3.0).

(C) Copyright C. Blaise et al., 2014

Licensee PAGEPress, Italy

Journal of Xenobiotics 2014; 4:4902

doi:10.4081/xeno.2014.4902

The experimental approach employed to assess interactive toxicity testing of PAMAM dendrimers with $\mathrm{MC}$ is illustrated in Figure lusing Hydra test data as an example. Briefly, starting with test concentrations of $1.5 \mathrm{mg} / \mathrm{L}$ for $\mathrm{G} 4$ and $50 \mathrm{mg} / \mathrm{L}$ for $\mathrm{MC}$, their individual EC50s were determined to be 1.25 and 15.2 $\mathrm{mg} / \mathrm{L}$, respectively (Figure $1 \mathrm{~A}$ and $\mathrm{B}$ ). Each EC50 was then expressed in \% v/v and then transformed to toxic units (TU), where $\mathrm{TU}=100 \% \mathrm{v} / \mathrm{v} \div \mathrm{EC} 50$ endpoint, respectively yielding TU values of 1.2 and 3.29 for $\mathrm{G} 4$ and MC (Figure 1A and B). Next, the interactive mixture was made up of a 1:1 mix of $3 \mathrm{mg} / \mathrm{L}$ of G4 and $100 \mathrm{mg} / \mathrm{L}$ of MC from which, following the same transformation protocol as above, a combined G4 and MC EC50 of 2.28 TUs was obtained (Figure 1C). From the three types of interaction results possible (Figure 1D), it stands that G4 and MC together display antagonism as their combined toxicity, where TUs $=2.28$ with $95 \%$ confidence intervals between $1.75-3.0$, is significantly less than the sum of their individual toxicities, where TUs $=4.49$ with $95 \%$ confidence intervals between 3.83-5.29 (Figure 1E).

Other interactive bioassays conducted with the same protocol as above (data not shown) demonstrated antagonism with the algal test $(\mathrm{G} 2+\mathrm{MC})$ and micro-crustacean test (G4+MC), additivity with the fish cell test (G5+MC), and synergism with the bacterial test (G4+MC). Such variable responses resulting from mixtures have been reported in the literature. For example, $V$. fischeri co-toxicity of $\mathrm{Cu} / \mathrm{PAH}$ was shown to be dependent on the 
ratio of concentrations of each chemical in the mixture and synergism, antagonism and additivity were observed with different combinations of $\mathrm{Cu}$ and PAHs. ${ }^{14}$ Again, the interactive effects of $\mathrm{Cu}$ and agrochemicals varied depending on the test species ( $V$. fischeri, $P$. subcapitata, D. magna) as well on the chemicals investigated and their respective concentrations. ${ }^{15}$

\section{Conclusions}

PAMAM dendrimers (G2, G4, G5) proved toxic to all of the taxonomic groups represented by the bioassays and the span of toxicity responses ranged from $0.082 \mathrm{mg} / \mathrm{L}$ (P. subcapitata IC25: G2) to $31.8 \mathrm{mg} / \mathrm{L}$ (V. fischeri IC25: G2). The most sensitive responses were generated by phototrophic (algae, LuminoTox) and $H$. attenuata toxicity tests which justifies their inclusion in future bioassay batteries aimed at determining the toxic potential of dendrimeric nanomaterials. Expectedly, MC was more toxic toward phototrophic (algae, LuminoTox) and bacterial (V. fischeri) species. Initial interac-

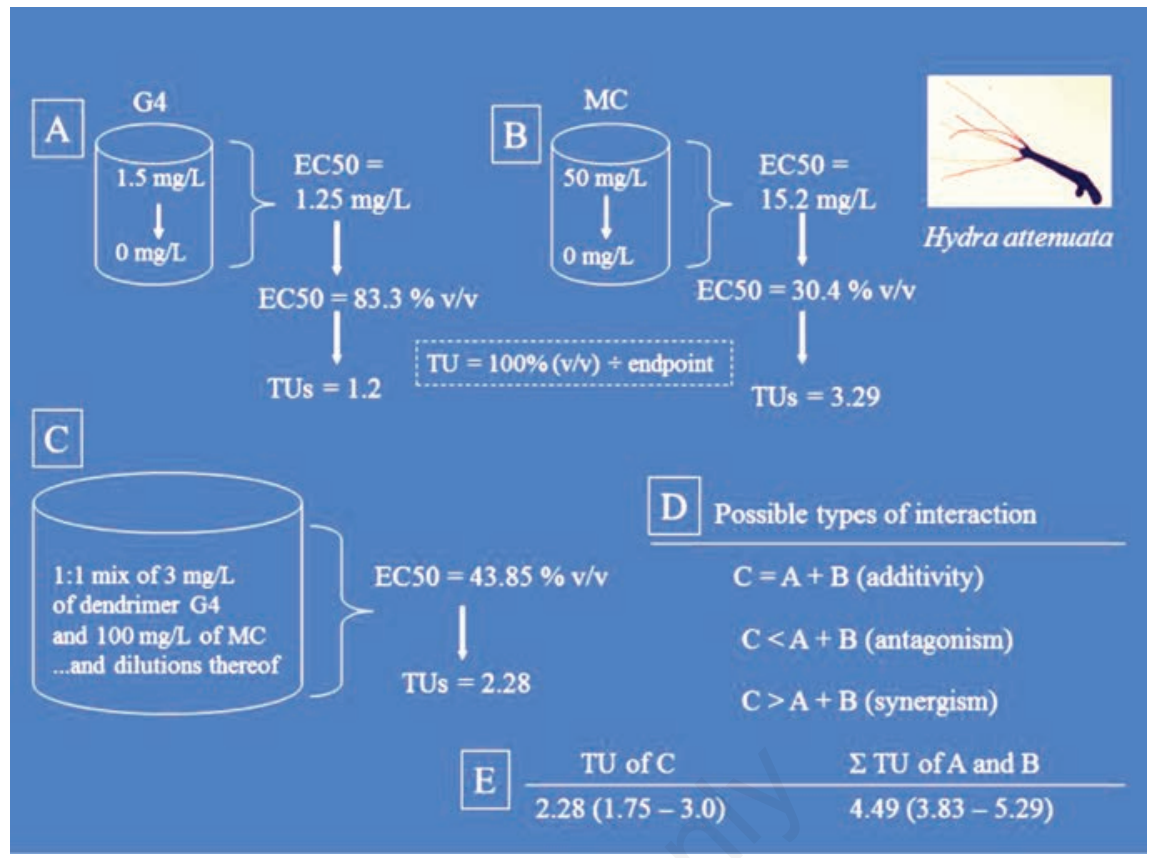

Figure 1. Experimental approach: PAMAM dendrimer G4 and minocycline (MC) interactive toxicity testing with the Hydra assay (see text for details).

Table 1. Characteristics of the small-scale bioassays used in this study.

\begin{tabular}{|c|c|c|c|c|}
\hline Trophic level & Toxicity test & Assessment endpoint & $\begin{array}{l}\text { Measurement } \\
\text { endpoint }\end{array}$ & Reference \\
\hline Decomposer & $\begin{array}{l}\text { Bacterial test Vibrio fischeri } \\
\text { (Microtox }^{\circledR} \text { toxicity test) }\end{array}$ & $\begin{array}{l}\text { Acute sublethal light inhibition } \\
\text { (after a 15-min exposure) }\end{array}$ & 15 min-IC25 & Environment Canada, $1992^{9}$ \\
\hline Primary producer & $\begin{array}{l}\text { Algal test (Pseudokirchneriella } \\
\text { subcapitata microplate assay) }\end{array}$ & $\begin{array}{l}\text { Chronic sublethal growth inhibition } \\
\text { (after a 72-h exposure) }\end{array}$ & 72 h-IC25 & Blaise and Vasseur, $2005^{10}$ \\
\hline Phototrophic assay & LuminoTox assay with PECs* & Inhibition of photosynthetic efficiency & $15 \min -\mathrm{IC} 20$ & $\begin{array}{l}\text { Lab_Bell Inc., } \\
\text { http://www.lab-bell.com }\end{array}$ \\
\hline Primary consumer & $\begin{array}{l}\text { Thamnocephalus platyurus } \\
\text { micro-crustacean test } \\
\text { (ThamnoTox kit assay) }\end{array}$ & Acute lethality (after a 24-h exposure) & 24 h-LC50 & $\begin{array}{l}\text { Microbiotests Inc., } \\
\text { http://www.microbiotests.be/ }\end{array}$ \\
\hline Secondary consumer & $\begin{array}{l}\text { Cnidarian test } \\
\text { (Hydra attenuata assay) }\end{array}$ & $\begin{array}{l}\text { Acute sublethality indicated by morphology } \\
\text { changes (after a } 96 \text {-h exposure) }\end{array}$ & 96 h-EC50 & Blaise and Kusui, $1997^{11}$ \\
\hline Secondary consumer & $\begin{array}{l}\text { Fish cell test } \\
\text { (rainbow trout primary } \\
\text { hepatocyte test) }\end{array}$ & Acute cytotoxicity (after a 48-h exposure) & $48 \mathrm{~h}-\mathrm{TEC}^{\circ}$ & Gagné, 2005 12 \\
\hline
\end{tabular}

NOEC=no observed effect concentration and LOEC=lowest observed effect concentration.

Table 2. Toxicity classification of dendrimers (G2, G4, G5) and minocycline (MC) based on European Union Commission Guideline 93/67/EEC ${ }^{13}$ and the most sensitive bioassay measurement endpoint values (LCx/ECx/ICx, etc.).

\begin{tabular}{lccccc} 
Chemical & $\begin{array}{c}\text { Extremely toxic } \\
(<0.1 \mathrm{mg} / \mathrm{L})\end{array}$ & $\begin{array}{c}\text { Very toxic } \\
(0.1-1 \mathrm{mg} / \mathrm{L})\end{array}$ & $\begin{array}{c}\text { Toxic } \\
(1-10 \mathrm{mg} / \mathrm{L})\end{array}$ & $\begin{array}{c}\text { Harmful } \\
(10-100 \mathrm{mg} / \mathrm{L})\end{array}$ & $\begin{array}{c}\text { Not toxic } \\
(>100 \mathrm{mg} / \mathrm{L})\end{array}$ \\
G2 & $\mathrm{A}^{*}$ & $\mathrm{H}$ & $\mathrm{F}, \mathrm{T}$ & $\mathrm{B}, \mathrm{L}$ & - \\
G4 & - & A, H, L & B, F, T & - & - \\
G5 & - & $\mathrm{A}, \mathrm{H}, \mathrm{L}$ & $\mathrm{F}, \mathrm{T}$ & $\mathrm{B}$ & - \\
MC & $\mathrm{A}$ & - & B, L & F, H & T \\
\hline
\end{tabular}

Toxicity tests: A, algal assay; B, bacterial assay; F, fish cell assay; H, Hydra assay; L, LuminoTox assay; T, ThamnoTox assay. *Example: for dendrimer G2, the green alga $P$. subcapitata gave the most sensitive response (72 h IC25=0.082 mg/L with lower and upper $95 \%$ confidence intervals of $0.069 \mathrm{mg} / \mathrm{L}$ and $0.097 \mathrm{mg} / \mathrm{L}$, respectively), thereby placing this compound in the extremely toxic category. 
tion experiments with dendrimers (G2, G4, G5) and MC demonstrate that mixture effects (antagonism, additivity, synergism) are trophic level dependent. The results suggest that these nanoproducts can be considered hazardous to aquatic life. In real life situations, risk to aquatic species will depend on quantities discharged to surface waters, on chemical interactions and on their bioaccumulation/biomagnification potential.

\section{References}

1. Kharu A, Ivask A. Mapping the dawn of nanoecotoxicological research. Accounts Chem Res 2013;46:823-33.

2. Nuñez-Anita RE, Acosta-Torres LS, VilarPineda J, Martínez-Espinosa JC, de la Fuente-Hernández J, Castaño VM. Toxicology of antimicrobial nanoparticles for prosthetic devices. Int J Nanomedicine 2014;9:3999-4006.

3. Turkez H, Sönmez E, Di Stefano A, Mokhtar YI. Health risk assessments of lithium titanate nanoparticles in rat liver cell model for its safe applications in nanopharmacology and nanomedicine. Cytotechnology 2014 [In press].
4. Blaise C, Gagné F, Férard JF, Eullaffroy P. Ecotoxicity of selected nano-materials to aquatic organisms. Environ Toxicol 2008;23:591-8.

5. Gagné $\mathrm{F}$, Gagnon C, Blaise C. Aquatic nanotoxicology - a review. Res Trends Curr Topics Toxicol 2008;4:1-14.

6. Cheng Y, Wang J, Rao T, He X, Xu T. Pharmaceutical applications of dendrimers: promising nanocarriers for drug delivery. Frontiers Biosci 2008;13:1447-71.

7. Cheng Y, Xu Z, Ma M, Xu T. Dendrimers as drug-carriers: applications in different routes of drug administration. $\mathrm{J}$ Pharmaceut Sci 2008;97:123-43.

8. Svenson S. Dendrimers as versatile platform in drug delivery applications. Eur J Pharm Biopharm 2009;71:445-62.

9. Environment Canada. Biological test method: toxicity test using luminescent bacteria (Photobacterium phosphoreum). Environmental Protection Series, Report EPS 1/RM/24. Ottawa: Conservation and Protection, Environment Canada; 1992. pp 61.

10. Blaise $C$, Vasseur P. Algal microplate toxicity test. In: Blaise C, Férard JF,(eds. Smallscale freshwater toxicity investigations, Vol. 1. Dordrecht: Springer; 2005. pp 137179.
11. Blaise C, Kusui T. Acute toxicity assessment of industrial effluents with a microplate-based Hydra attenuata assay. Environ Toxicol Water Qual 1997;12:53-60.

12. Gagné F. Acute toxicity assessment of liquid samples with primary cultures of rainbow trout hepatocytes. In: Blaise $\mathrm{C}$, Férard JF,(eds. Small-scale freshwater toxicity investigations, Vol. 1. Dordrecht: Springer; 2005. pp 453-472.

13. CEC (Commission of the European Communities). Technical guidance document in support of commission directive 93/67/EEC on risk assessment for new notified substances. Part II, Environmental Risk Assessment. Luxembourg: Office for official publications of the European Communities; 1996.

14. Wang W, Lampi M, Huang X, Gerhardt, Dixon G, Greenberg B. Assessment of mixture toxicity of copper, cadmium and phenanthrenequinone to the marine bacterium Vibrio fischeri. Environ Toxicol 2009;24:166-77.

15. Kungolos S, Emmanouil C, Tsiridis V, Tsiropoulos N. Evaluation of toxic and interactive toxic effects of three agrochemicals and copper using a battery of microbiotests. Sci Total Env 2009;407: 4610-15. 